Gut, 1973, 14, 341-347

\title{
Value of small intestinal bile acid analysis in the diagnosis of the stagnant loop syndrome
}

\author{
T. C. NORTHFIELD, B. S. DRASAR, AND J. T. WRIGHT \\ From the Departments of Medicine and Biochemistry, Guy's Hospital, Wright-Fleming Institute of Micro- \\ biology, St Mary's Hospital, and the London Hospital, London
}

SUMMARY We have studied simple methods of analysing bile acids in human small intestinal aspirates, in order to assess their suitability for the routine clinical investigation of patients with steatorrhoea. Following extraction into methanol, samples were analysed qualitatively for bile acid deconjugation by thin-layer chromatography and quantitatively by the 3-alpha-hydroxysteroid dehydrogenase enzyme assay. These methods were found to give good recoveries, and to be sensitive, accurate, and specific, in addition to being sufficiently simple and rapid for routine diagnostic purposes.

This diagnostic procedure was applied to the identification of patients with steatorrhoea due to the stagnant loop syndrome, and was compared with other tests for this condition, viz, study of the small intestinal bacterial flora, urinary indican excretion, and the Schilling test with added intrinsic factor. Three groups of subjects were studied; group I consisted of nine patients with steatorrhoea due to the stagnant loop syndrome; group II (disease control group) of six patients with an anatomical stagnant loop that was not causing steatorrhoea; and group III (normal control group) of 11 subjects with no known gastrointestinal disease. The screening of postprandial upper jejunal samples for bile acid deconjugation proved the most useful diagnostic test, being positive in eight out of nine patients from group I, but in none of those from groups II and III. At lower levels of the small intestine, bile acid deconjugation was found in subjects from groups II and III. The other three diagnostic tests discriminated poorly between subjects from group I and those from group II.

The major diagnostic problem in the stagnant loop syndrome is to determine whether bacterial overgrowth in the small intestine is the cause of steatorrhoea in a patient with multiple pathological conditions of the small bowel, including an anatomical stagnant loop. A common example of this is the patient with Crohn's disease complicated by a stricture or fistula. This patient's malabsorption syndrome might be due to bacterial overgrowth resulting from the stricture or fistula, in which case it should respond to surgical treatment or antibiotics; alternatively, it might be due to mucosal involvement by Crohn's disease. An answer could be obtained by measuring the faecal fat excretion before and after a course of a broad-spectrum antibiotic. But this would require hospitalization for a period of at least 10 days and would thus be timeconsuming and expensive.

Received for publication 21 February 1973.
Various indirect tests for bacterial overgrowth have therefore been introduced in order to resolve this problem, but none of them has proved entirely satisfactory. Urinary indican excretion is raised in patients with bacterial overgrowth of the small intestine, but mild to moderately increased levels are also found in patients with other malabsorption syndromes (Neale and Tabaqchali, 1966; Greenberger, Saegh, and Ruppert, 1968). The Schilling (1953) test is abnormal even in the presence of added intrinsic factor, but an abnormal test is found in patients with ileal disease or resection. Recently, a breath test has been introduced for altered bile acid metabolism (Fromm and Hofmann, 1971), but this is also positive in patients with bile acid malabsorption due to ileal disease or resection.

In view of the nonspecific nature of these indirect tests, we have taken a more direct approach to diagnosis. Current evidence suggests that steatorrhoea in the stagnant loop syndrome is due to bac- 
terial deconjugation of bile acids within the lumen of the small intestine (Donaldson, 1965; Tabaqchali, Hatzioannou, and Booth, 1968). If this is true, then screening of small intestinal aspirates for bile acid deconjugation ought to provide the most direct approach to diagnosis. We have therefore assessed this method of diagnosis in nine patients with steatorrhoea due to the stagnant loop syndrome, and have compared it with study of the small intestinal bacterial flora, urinary indican excretion, and the Schilling test with added intrinsic factor. In view of recent evidence that bacterial deconjugation of bile acids occurs in the lower jejunum and ileum of normal subjects (Northfield, Condillac, and McColl, 1970), we have also studied 11 subjects with no known gastrointestinal disease (normal control group), and a group of six subjects with an anatomical stagnant loop that was not giving rise to steatorrhoea (disease control group). A preliminary report of our findings was presented at the annual meeting of the British Society of Gastroenterology in 1971 (Northfield, Drasar, and Wright, 1971).

\section{Material and Methods}

\section{SUBJECTS}

Three groups of subjects were studied. Subjects in groups I and II all had a radiologically demonstrated anatomical abnormality of the small intestine, of a sort that is known to be capable of giving rise to the stagnant loop syndrome. Six subjects had small intestinal diverticula, five had a small intestinal stricture, and four had a fistula between the small and large intestine. Group I consisted of nine patients with steatorrhoea attributed to the stagnant loop syndrome (see table). In four of these patients (group Ia) there was no other detectable cause for steatorrhoea. Three of them were treated with ampicillin, with a reduction in faecal fat excretion. In the other five (group Ib) there was an alternative cause for steatorrhoea, but treatment resulted in a reduction in faecal fat excretion to normal (less than $5 \mathrm{~g}$ daily) in four patients, and from $27 \mathrm{~g}$ to $8 \mathrm{~g}$ daily in the fifth. Treatment consisted of oral ampicillin $(250 \mathrm{mg}$ six hourly for six days) in three patients, relief of subacute small intestinal obstruction by surgical resection in one patient, and rapid clinical and radiological relief of subacute small intestinal obstruction coincident with oral administration of azathioprine for Crohn's disease in the other. Group II formed the disease control group, and consisted of six patients with an anatomical stagnant loop that was not considered to be the cause of steatorrhoea. Three of these patients did not have steatorrhoea (group IIa). The other three had steatorrhoea, an alternative cause for this, and no decrease in faecal fat excretion following oral ampicillin.

Group III formed the normal control group and consisted of 11 inpatients, none of whom had known gastrointestinal disease or gastrointestinal symptoms. The general physical state of all the patients was

\begin{tabular}{|c|c|c|c|c|c|c|}
\hline Case & Group & Age & Sex & Stagnant Loop & Other Cause for Steatorrhoea & Clinical Presentation \\
\hline 1 & IA & 70 & $\mathbf{F}$ & Gastrocolic fistula & Nil & $\begin{array}{l}\text { Diarrhoea, faecal vomiting, } \\
\text { weight loss }\end{array}$ \\
\hline 2 & IA & 64 & $\mathbf{M}$ & Jejunal diverticulosis & Nil & Steatorrhoea and weight loss \\
\hline 3 & IA & 68 & $\mathbf{F}$ & $\begin{array}{l}\text { Ileal stricture } \\
\text { (probably ischaemic) }\end{array}$ & Nil & $\begin{array}{l}\text { Sixteen years of attacks of } \\
\text { subacute obstruction } \\
\text { plus steatorrhoea }\end{array}$ \\
\hline 4 & IA & 78 & $\mathbf{F}$ & Large duodenal diverticulum & Nil & $\begin{array}{l}\text { Megaloblastic anaemia and } \\
\text { weight loss }\end{array}$ \\
\hline 5 & IB & 59 & $\mathbf{M}$ & $\begin{array}{l}\text { Jejunal obstruction } \\
\text { (due to adhesions) }\end{array}$ & Polya gastrectomy & $\begin{array}{l}\text { Episodes of subacute } \\
\text { obstruction plus diarrhoea }\end{array}$ \\
\hline 6 & IB & 51 & $\mathbf{M}$ & Jejunal stricture & Crohn's disease of ileum & Subacute obstruction \\
\hline 7 & IB & 85 & $\mathbf{F}$ & $\begin{array}{l}\text { Two large duodenal } \\
\text { diverticula }\end{array}$ & Polya gastrectomy & $\begin{array}{l}\text { Malnutrition, megaloblastic } \\
\text { anaemia }\end{array}$ \\
\hline 8 & IB & 69 & $\mathbf{M}$ & Duodenocolic fistula & Polya gastrectomy & Malnutrition \\
\hline 9 & IB & 47 & $\mathbf{M}$ & Jejunal stricture & $\begin{array}{l}\text { Crohn's disease } \\
\text { Ileal resection }\end{array}$ & $\begin{array}{l}\text { Subacute obstruction and } \\
\text { steatorrhoea }\end{array}$ \\
\hline 10 & IIA & 70 & $\mathbf{F}$ & Jejunal and ileal diverticula & Nil & Megaloblastic anaemia \\
\hline 11 & IIA & 66 & $\mathbf{F}$ & Duodenal diverticulum & Nil & Depression and weight loss \\
\hline 12 & IIA & 69 & $\mathbf{M}$ & Three duodenal diverticula & Nil & Incidental finding \\
\hline 13 & IIB & 19 & $\mathbf{M}$ & Ileocolic fistula & Crohn's disease of ileum & Diarrhoea and weight loss \\
\hline 14 & IIB & 20 & $\mathbf{M}$ & Ileocolic fistula & Ileal bypass for obstruction & $\begin{array}{l}\text { Steatorrhoea Fe-deficient } \\
\text { anaemia }\end{array}$ \\
\hline 15 & IIB & 57 & $\mathbf{M}$ & Ileal stricture & $\begin{array}{l}\text { Crohn's disease } \\
\text { Ileal resection }\end{array}$ & $\begin{array}{l}\text { Episodes of subacute } \\
\text { obstruction plus diarrhoea }\end{array}$ \\
\hline
\end{tabular}

Table I Clinical details of patients with an anatomical stagnant loop 
good at the time of the investigation. None of them had been treated with antibiotics during the previous month, nor had they received any other drugs apart from night sedation during the previous week. Their ages ranged from 21 to 66 (mean 47 years). Ten subjects were male, one female.

\section{INTUBATION AND SAMPLING}

Samples were obtained by a modified rapid transit tube (Wiggins, Cook, and McLeod, 1967). The triple-lumen tube was passed via the nasal route before breakfast on the day of the study, following an overnight fast. A fasting sample was obtained, after which the subject proceeded to eat a normal ward diet of three meals daily. The postprandial upper jejunal sample was obtained approximately 30 minutes after breakfast and all other samples were obtained within two hours of eating. The position of the aspiration site was checked radiologically at the duodenojejunal flexure in all subjects, and also at the ileocaecal valve in the six normal controls in whom this level was reached. The site of aspiration at other levels was determined by measurements of tube length.

\section{BILE ACID ANALYSIS}

Samples $(2-10 \mathrm{ml})$ were immediately frozen at $-10^{\circ} \mathrm{C}$, and were stored at this temperature. Before analysis, a small aliquot $(1 \mathrm{ml})$ was evaporated to dryness. The dry residue was extracted three times with redistilled methanol, with thorough mixing followed by filtration and evaporation to small volume. Qualitative analysis was carried out by thin-layer chromatography on Keiselgel G. For identification of free bile acids, the solvent systems S7 and S11 of Eneroth (1963) were used, and for conjugated bile acids the system of Anderson and Haslewood (1970). Plates were developed with $10 \%$ phosphomolybdic acid in ethanolic solution. Quantitative measurements of total bile acid concentration were carried out using the 3-alphahydroxysteroid dehydrogenase enzyme assay (Iwata and Yamasaki, 1964). In small intestinal samples containing free bile acids the concentrations of free and conjugated bile acids were measured individually by this method, following separation as streaks by thin-layer chromatography. Following nondestructive development in an iodine chamber, the appropriate strips of Keiselgel were scraped off and extracted with redistilled methanol.

\section{BACTERIOLOGY}

For bacteriological studies, small intestinal samples were diluted tenfold in glycerol broth, and immediately frozen at $-10^{\circ} \mathrm{C}$. Aerobic and anaerobic cultures were carried out subsequently according to the methods of Drasar and Crowther (1971).

URINARY INDICAN EXCRETION

This was measured by the method of Curzon and Walsh (1962). The upper limit of normal is $100 \mathrm{mg} /$ 24 hours on an ordinary ward diet.

\begin{tabular}{|c|c|c|c|c|c|}
\hline \multirow{2}{*}{$\begin{array}{l}\text { Urinary } \\
\text { Indican } \\
(m g / 24 h r)\end{array}$} & \multicolumn{2}{|c|}{ Before Treatment } & \multicolumn{2}{|c|}{ After Treatment } & \multirow[t]{2}{*}{ Treatment } \\
\hline & $\begin{array}{l}\text { Faecal Fats } \\
(\mathrm{g} \text { daily) }\end{array}$ & $\begin{array}{l}\text { Schilling Test } \\
(+I F)\end{array}$ & $\begin{array}{l}\text { Faecal Fats } \\
(\mathrm{g})\end{array}$ & Schilling Test & \\
\hline- & $11 \cdot 8$ & $9 \%$ & $9 \cdot 0$ & $21 \%$ & Polya gastrectomy \\
\hline $\begin{array}{l}356 \\
340\end{array}$ & $\begin{array}{l}15 \\
25\end{array}$ & $\begin{array}{l}7 \cdot 5 \% \\
2 \cdot 6 \%\end{array}$ & $\begin{array}{r}8 \cdot 3 \\
11 \cdot 6\end{array}$ & $\begin{array}{r}12.5 \% \\
1.5 \%\end{array}$ & $\begin{array}{l}\text { Ampicillin } \\
\text { Ampicillin }\end{array}$ \\
\hline 137 & $5 \cdot 5$ & $19 \cdot 6 \%$ & 3 & - & Ampicillin \\
\hline 183 & 5.9 & $0.3 \%$ & $3 \cdot 2$ & $13 \%$ & Ampicillin \\
\hline 369 & $7 \cdot 6$ & $7 \cdot 8 \%$ & $3 \cdot 8$ & $12 \%$ & $\begin{array}{l}\text { Relief of obstruction following } \\
\text { azathioprine }\end{array}$ \\
\hline 94 & $6 \cdot 7$ & $2 \cdot 2 \%$ & $4 \cdot 7$ & $6.9 \%$ & Ampicillin \\
\hline $\begin{array}{r}20 \\
-\end{array}$ & $\begin{array}{l}27 \\
10\end{array}$ & $\begin{array}{l}17 \% \\
-\end{array}$ & $\begin{array}{r}8 \\
17 \\
4\end{array}$ & - & $\begin{array}{l}\text { Ampicillin } \\
\text { Repair of fistula } \\
\text { Surgical resection of stricture }\end{array}$ \\
\hline $\begin{array}{r}255 \\
88 \\
152 \\
312 \\
212\end{array}$ & $\begin{array}{l}4.1 \\
3.7 \\
3.7 \\
8 \\
5.9\end{array}$ & $\begin{array}{l}7 \% \\
16 \% \\
18.9 \% \\
2.9 \% \\
0.7 \%\end{array}$ & $\begin{array}{l}\bar{z} \\
\overline{12} \\
6.9\end{array}$ & $\begin{array}{l}21 \% \\
\overline{3} .8 \% \\
0.3 \%\end{array}$ & $\begin{array}{l}\text { Ampicillin } \\
\overline{-} \\
\text { Ampicillin } \\
\text { Ampicillin }\end{array}$ \\
\hline 198 & 42 & $7 \cdot 4 \%$ & 50 & - & Ampicillin \\
\hline
\end{tabular}


FAECAL FAT EXCRETION

Total fatty acids were measured by the method of van der Kamer, ten Bokkel Huinink, and Weyers (1949). The result given is the mean daily excretion (normal $<5 \mathrm{~g}$ daily), based on a collection period of three to five successive days. The subjects were eating a normal ward diet containing approximately $75 \mathrm{~g}$ fat daily.

VITAMIN B 12 ABSORPTION

This was measured by the Schilling test (Schilling, 1953) using $0.5 \mu \mathrm{g}{ }^{68} \mathrm{CO}$ vitamin $\mathrm{B}_{12}$ orally, and $1 \mathrm{mg}$ stable vitamin $B_{12}$ intramuscularly, with the urine radioactivity in the first 24 hours expressed as a percentage of the oral dose (normal $>10 \%$ ). Hog intrinsic factor, $50 \mathrm{mg}$, was given with the oral dose.

\section{Results}

VALIDATION AND PRACTICABILITY OF SMALL INTESTINAL BILE ACID ANALYSIS

\section{Recoveries}

In order to determine the degree of recovery attained by the initial extraction procedure, known amounts of bile acid standards (more than $95 \%$ pure by thin-layer chromatography) were added to intestinal fluid of known bile acid content. The fluid was then subjected to the usual methanol extraction procedure and the recovery measured enzymatically. For free cholic, chenodeoxycholic and deoxycholic acid, recoveries were $75-80 \%$. For the glycine and taurine conjugates of these three bile acids, recoveries were $85-90 \%$. In order to determine recovery following elution from silica gel, known amounts of bile acid standards were run on a thinlayer plate and then extracted. The recovery of both free and conjugated bile acids, measured enzymatically, was $85 \%$.

\section{Sensitivity}

The minimum amount of 2 . bile acid standard detectable on a thin-layer chromatogram was $5 \mu \mathrm{g}$ $(0.01 \mu$ moles $)$. The minumum amount distinguishable from background values by the enzyme assay was $10 \mu \mathrm{g}(0.02 \mu \mathrm{moles})$.

\section{Specificity}

All the silica gel was eluted in bands from several thin-layer chromatograms of intestinal juice and then assayed enzymically. Only those bands corresponding to known bile acid standards gave positive values for the enzyme assay.

Calibration

Straight line calibration was obtained in each case, with addition to the cuvette of up to $100 \mu \mathrm{g}$ of free cholic, deoxycholic, and chenodeoxycholic acid, and of the glycine and taurine conjugates of these three bile acids.

\section{Reproducibility}

Methanol extraction and enzymic assay for total bile acid concentration were carried out on completely separate occasions in the case of 10 different samples of intestinal juice. The coefficient of variation was $\mathbf{7 \cdot 8 \%}$. Intestinal juice from a patient with the stagnant loop syndrome was divided into three aliquots. These were extracted separately, and the concentration of conjugated bile acids, of free cholic acid, and of free dihydroxy bile acids was estimated separately by the combined procedure of thin-layer chromatography and enzymic assay. The coefficient of variation was $6.8 \%$ in the case of the conjugated bile acids, $4.6 \%$ in the case of free cholic acid, and $7 \cdot 2 \%$ in the case of the free dihydroxy bile acids.

\section{Practicability}

With practice, at least four samples can be extracted, screened for free bile acids, and analysed enzymically for total bile acid concentration by one person in a single eight-hour day. The additional time needed for the separate quantitative measurement of conjugated and free bile acids is about six hours per sample.

APPLICATION TO DIAGNOSIS OF THE STAGNANT LOOP SYNDROME

These methods of small intestinal bile acid analysis were applied to the diagnosis of steatorrhoea due to the stagnant loop syndrome. A thin-layer chromatogram of an extract of upper jejunal juice from a normal control and from a patient in group I with steatorrhoea due to the stagnant loop syndrome is shown as an example (fig 1). The sample from the stagnant loop syndrome patient shows the presence of three spots corresponding in position to standard samples of free (unconjugated) cholic, chenodeoxycholic, and deoxycholic acid. The sample from the normal control contains no spots corresponding to the free bile acid standards. The two spots close to the origin (on the left) in the normal subject represent bile acids conjugated with taurine and glycine. There is much less glycine conjugate in the sample from the patient with the stagnant loop syndrome.

Figure 2 shows the percentage deconjugation of bile acids (defined as the percentage of the total bile acid concentration present in the free or unconjugated form) in samples obtained from various levels of the small intestine. Postprandial upper jejunal samples discriminated better than fasting samples 
Free bile acid standards

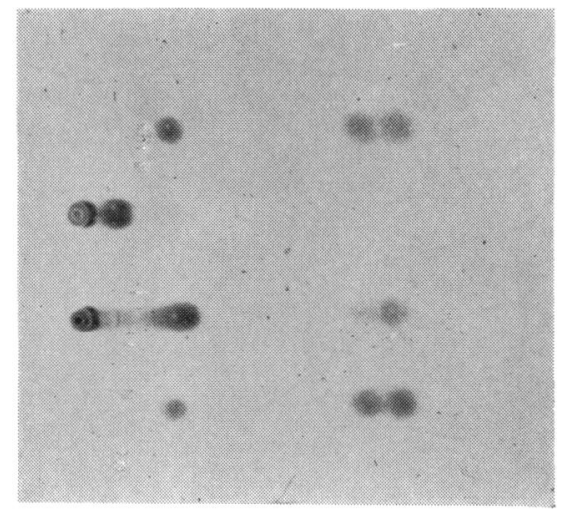

Fig 1 Representative thin-layer chromatogram of methanolic extracts of postprandial upper jejunal aspirates.

between patients from group I and those from group II. In the postprandial samples, eight out of nine group I subjects, with steatorrhoea attributable to the stagnant loop syndrome, showed the presence of bile acid deconjugation. By contrast, bile acid deconjugation was not detected at this level in any of the five group II subjects $\left(\chi^{2}=7 \cdot 1 ; P<0.01\right)$, nor in any of the nine group III subjects $\left(\chi^{2}=11 \cdot 0\right.$; $P<0.005)$. The ninth group I subject showed the presence of bile acid deconjugation in a lower jejunal sample, but so did one out of three group II subjects, and two out of 11 group III subjects, although to a lesser degree. Ileal samples had no diagnostic value in this study since deconjugation of up to $100 \%$ was found in two disease controls (group II) and in seven out of 10 normal controls (group III).

COMPARISON WITH OTHER DIAGNOSTIC TESTS With respect to the bacteriological findings, the anaerobe counts gave more useful information than did the aerobe counts. Total anaerobe counts are shown in fig 3 for the same levels of the small intestine as in figure 2 . As with the bile acid results, the postprandial upper jejunal sample discriminated better than the fasting sample between the two groups of patients studied. Five out of seven group I subjects had a count higher than the normal range found.in the group III subjects, ie, more than $10^{4}$ per $\mathrm{ml}$, but so did three out of five group II subjects

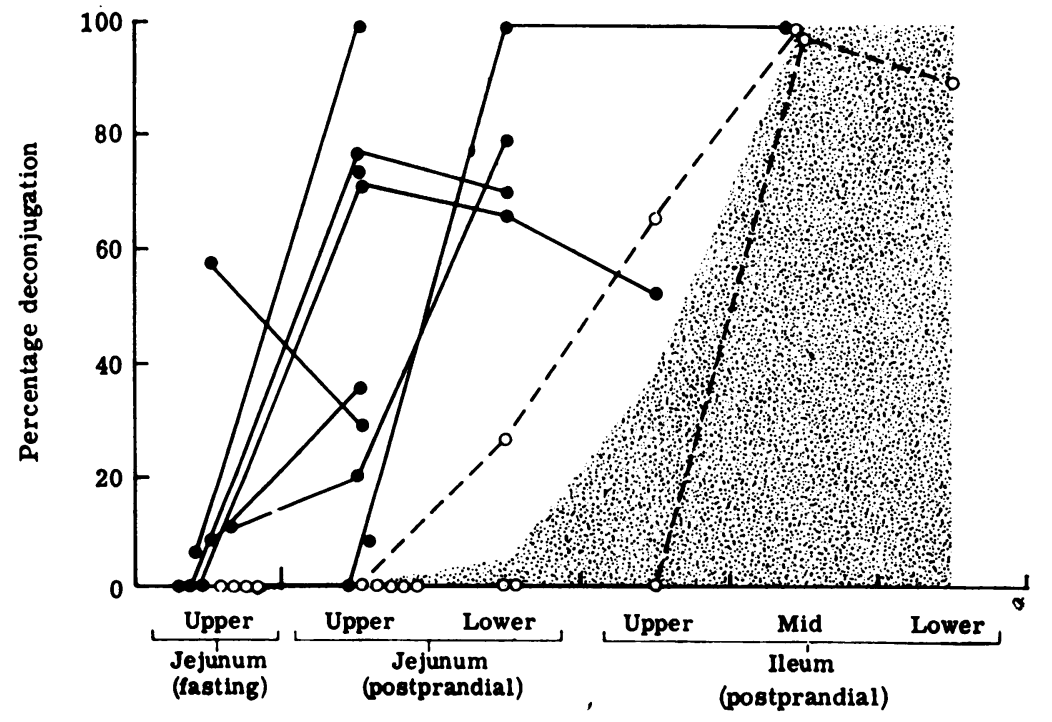

Fig 2 Percentage bile acid deconjugation at multiple sites in the small intestine. (Closed circles represent group I subjects, open circles group II subjects, and hatched area represents normal range based on subjects from group III.) 


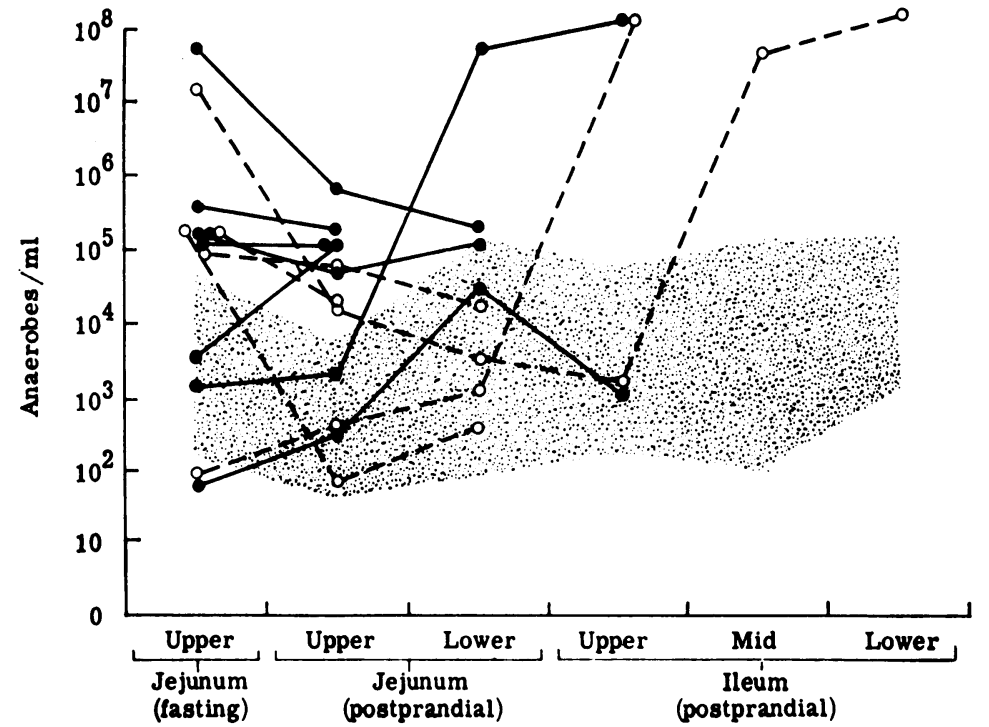

$\left(\chi^{2}=0.04 ; 0.75<\mathrm{P}<0.9\right)$. Four group I subjects had a count of more than $10^{5}$ per $\mathrm{ml}$, whereas no group II subject had a count above this level, but this difference also may have been due to chance $\left(\chi^{2}=2 \cdot 1 ; 0 \cdot 1<\mathrm{P}<0 \cdot 25\right)$. Two patients from both these groups had a count within the normal range. Three of these four patients had a raised count at some other level of the small intestine. The fourth patient had a lower ileal stricture, and it is possible that if a sample had been available from mid or lower ileum this would have shown a raised count. In all cases, testing in vitro showed that the anaerobes were sensitive to ampicillin before treatment with this antibiotic. They consisted mainly of bacteroides and bifidobacteria, which were capable of deconjugating bile acids in vitro.

The urinary indican excretion in group I subjects was $214 \pm 141 \mathrm{mg}$ per 24 hours (mean \pm SD), and a very similar excretion of $202 \pm 78 \mathrm{mg}$ per 24 hours was found in group II subjects. Five out of seven group I subjects had an increased excretion (more than $100 \mathrm{mg} / 24$ hours), but so did five out of six group II patients (table I). The three highest values came from subjects in group I.

The Schilling test with added intrinsic factor also gave similar values in subjects from group I $(8 \cdot 2 \pm$ $7.0 \%)$ and group II $(8 \cdot 8 \pm 7 \cdot 2 \%)$. Six out of eight group I patients had a reduced vitamin $B_{12}$ excretion (less than $10 \%$ ), but so did four out of six group II patients. Further understanding of these results can be obtained from the clinical details and from the results of antibiotic therapy (table I). Three of the four group II patients having an abnormal Schilling test had ileal Crohn's disease, or an ileal bypass or
Fig 3 Total anaerobe counts at multiple sites in the small intestine. (Symbols are the same as for fig 2.)

resection (cases 13,14 , and 15). Two of these three patients had a repeat Schilling test, following a course of oral ampicillin, without any improvement. The fourth patient (case 10) had widespread jejunal and ileal diverticulosis, and the Schilling test returned to normal following ampicillin. This patient presented with megaloblastic anaemia, but had no steatorrhoea. A dissociation between fat and vitamin $\mathbf{B}_{12}$ absorption was also found in two group I patients (cases 4 and 8), who had steatorrhoea attributed to the stagnant loop syndrome, but normal vitamin $\mathbf{B}_{\mathbf{1 2}}$ absorption.

\section{Discussion}

The methods of jejunal bile acid analysis described here are sensitive, accurate, and specific. Furthermore, they are sufficiently simple and rapid for use as a routine diagnostic procedure in a laboratory not having any special experience in bile acid chemistry. A major factor in the speed of the analysis was the use of a simple methanol extraction procedure, and this gave satisfactory recoveries for both free and conjugated bile acids. The lengthiest procedure used here was the individual measurement of free and conjugated bile acid concentration, following thinlayer chromatography, but this procedure can usually be omitted.

In applying jejunal bile acid analysis to the identification of patients with steatorrhoea due to the stagnant loop syndrome, the most useful diagnostic information was obtained from screening postprandial upper jejunal samples for the presence of bile acid deconjugation. This can be carried out on a 
purely qualitative basis, by thin-layer chromatography, so long as a positive result is checked on a second solvent system. Observing this precaution, we found no false positive results, and only one false negative result. It should be noted that the number of subjects studied was relatively small, so that our findings require confirmation in a larger series. In the meantime, it is probably advisable to check the significance of a positive result by assessing the response of faecal fat excretion to a broad-spectrum antibiotic.

Comparison with other procedures showed that jejunal bile acid analysis was of more diagnostic value in determining the cause of steatorrhoea than study of the small intestinal bacterial flora. Anaerobe counts of up to $10^{4}$ per $\mathrm{ml}$ were found in postprandial upper jejunal samples of normal subjects. These counts are higher than those reported by other authorities (Gorbach, 1971). Urinary indican excretion and Schilling test with added intrinsic factor discriminated poorly between patients with the stagnant loop syndrome and disease controls. Although we have not compared jejunal bile acid analysis directly with the radioisotope breath test for altered bile acid metabolism, which was first described after completion of our study (Fromm and Hofmann, 1971), it should be noted that this latter test cannot give any information on the site of increased bile acid deconjugation. A positive result is also obtained with increased colonic deconjugation in patients with bile acid malabsorption due to ileal disease or resection. Interpretation would therefore be particularly difficult with respect to the main diagnostic problem studied here-the patient with multiple pathological conditions of the small bowel. The breath test does, however, appear to be a simple method of selecting patients for more detailed diagnostic investigation (Parkin, O'Moore, Cussons, Warwick, Rooney, Percy-Robb, and Shearman, 1972). The interpretation of a positive test should be assisted by direct determination of the site of bile acid deconjugation by means of jejunal intubation, as described here.

Jejunal bile acid analysis could probably be usefully applied as a diagnostic test in patients with steatorrhoea due to other causes than the stagnant loop syndrome, especially when there is more than one possible cause for steatorrhoea. A reduced jejunal concentration of total bile acids has been reported in patients with steatorrhoea due to ileal resection (McLeod and Wiggins, 1968) and chronic liver disease (Badley, Murphy, Bouchier, and Sherlock, 1970). In these conditions, bile acid deconjugation is not found in upper jejunal samples, so that differentiation from the stagnant loop syndrome, as well as from other malabsorption syndromes, should be possible. Aspirates for jejunal bile acid analysis can be obtained at the same time as a Lundh test of pancreatic function (Lundh, 1962).

We are very grateful to Professor G. A. D. Haslewood for much helpful advice and encouragement, and in particular for his suggestion of the methanol extraction procedure. We are also grateful to $\mathrm{Mr}$ Edmund Condillac for his valuable technical assistance. This work was supported by grants from the Medical Research Council and from the Wellcome Trust.

\section{References}

Anderson, I. G., and Haslewood, G. A. D. (1970). Comparative studies of bile salts. Biochem. J., 116, 581-587.

Badley, B. W. D., Murphy, G. M., Bouchier, I. A. D., and Sherlock, S. (1970). Diminished micellar phase lipid in patients with chronic nonalcoholic liver disease and steatorrhea. Gastroenterology, 58, 781-789.

Curzon, G., and Walsh, J. (1962). A method for the determination of urinary indoxyl sulphate (indican). Clin. chim. Acta, 7, 657-663.

Donaldson, R. M., Jr. (1965). Studies on the pathogenesis of steatorrhea in the blind loop syndrome. J. clin. Invest., 44, 1815-1825.

Drasar, B. S., and Crowther, J. S. (1971). The cultivation of human intestinal bacteria. In The Isolation of Anaerobes (Society for Applied Bacteriology, Tech. Ser., no. 5), edited by D. A. Shapton and R. G. Board. Academic Press, London.

Eneroth, P. (1963). Thin-layer chromatography of bile acids. J. Lipid Res., 4, 11-16.

Fromm, H., and Hofmann, A. F. (1971). Breath test for altered bileacid metabolism. Lancet, 2, 621-625.

Gorbach, S. L. (1971). Intestinal microflora. Gastroenterology, 60, 1110-1129.

Greenberger, N. J., Saegh, S., and Ruppert, R. D. (1968). Urine indican excretion in malabsorptive disorders. Gastroenterology, $55,204-211$.

Iwata, T., and Yamasaki, K. (1964). Enzymatic determination and thin-layer chromatography of bile acids in blood. J. Biochem. (Tokyo), 56, 424-431.

Lundh, G. (1962). Pancreatic exocrine function in neoplastic and inflammatory disease: A simple and reliable new test. Gastroenterology, 42, 275-280.

McLeod, G. M., and Wiggins, H. S. (1968). Bile-salts in small intestinal contents after ileal resection and in other malabsorption syndromes. Lancet, 1, 873-876.

Neale, G., and Tabaqchali, S. (1966). Value of measuring urinary indican excretion. (Abstr.) Gut, 7, 711.

Northfield, T. C., Condillac, E., and McColl, I. (1970). Bile salt metabolism in the normal human small intestine. (Abstr.) Gut, $11,1063$.

Northfield, T. C., Drasar, B. S., and Wright, J. T. (1971). Diagnostic tests for the stagnant loop syndrome. (Abstr.) Gut, 12, 857.

Parkin, D. M., O'Moore, R. R., Cussons, D. J., Warwick, R. R. G., Rooney, P., Percy-Robb, I. W., and Shearman, D. J. C. (1972). Evaluation of the 'breath test' in the detection of bacterial colonization of the upper gastrointestinal tract. Lancet, 2, 777-780.

Schilling, R. F. (1953). Intrinsic factor studies. II. The effect of gastric juice on the urinary excretion of radioactivity after the oral administration of radioactive vitamin $\mathbf{B}_{12}$. J. Lab. clin. Med., 42, 860-866.

Tabaqchali, S., Hatzioannou, J., and Booth, C. C. (1968). Bile salt deconjugation and steatorrhoea in patients with the stagnant loop syndrome. Lancet, 2, 12-16.

van de Kamer, J. H., ten Bokkel Huinink, H., and Weyers, H. A. (1949). Rapid method for the determination of fat in feces. J. biol. Chem., 177, 347-355.

Wiggins, H. W., Cook, H. B., and McLeod, G. M. (1967). A technique for the controlled sampling of small intestinal contents Tydschr. Gastroent., 10, 64-76. 